\title{
Relationship between power strength and anaerobic power index as a clear picture of the effect of strength training among young soccer elite players
}

\author{
Mohammed Zerf 1 \\ Mohamed Arab. Kerroum ${ }^{1}$ \\ Bouabdellah S.B.A. ${ }^{2}$
}

\author{
${ }^{1}$ Institute of Physical Education and Sport, University of \\ Mostaganem, Mostaganem, Algeria \\ ${ }^{2}$ University Hassiba Ben Bouali of Chlef, Algeria
}

\begin{abstract}
Purpose: muscle contraction has both mechanical to produce movement and metabolic properties to produce energy. However, manipulation of strength training planes (horizontal or vertical) subject to be an important training strategy to develop soccer-specific power-based actions. Depending on mode of exercise and more important the energy demands.

Material \& Methods: this cross-sectional study was conducted to inspect the relation between power strength and anaerobic power index, proper to mode of exercise (vertical vs horizontal) among young soccer elite players. To achieve this goal, we based on anaerobic capacity repeat sprint test power index for 103 male players with mean age (18.55 \pm 0.48$)$ years, involved in the Oran league competition division one. In addition to their strength in Vertical Jump (VJ) and Standing Long Jump Test $(S L J)$, conducted in the Omni sports complex of the institute physical education and sport Chlef.

Results: significant inverse correlations record between power strength and anaerobic power index in all comparisons practised. Support by the index of Max power anaerobic and fatigue as super predictors of players performance in horizontal plane. The opposite of vertical plane where the index of fatigue and Min power anaerobic are the super predictors.

Conclusions: our results confirmed that to have a clear picture of the effect of strength training on physical performance. Trainers must take in their consideration, the mode of exercise and their energy index power demands affirmed in present via the development of max power anaerobic to enhance not only minimal but also the index of fatigue requiring the good developments of neuromuscular function, in which max power anaerobic levels play a big part in maximizing scores not only in vertical plane but also in horizontal jump.
\end{abstract}

Keywords: youth training athletes, strength and conditioning, sports performance.

\section{Introduction}

Coaching is the 'degrees of freedom' that might be expected in sports preparation and performance, given the complexity involved. Admitted as a multidimensional process to identify promotes talents [1]. Founded on critical predictors' factor of sports type game success permitting the athlete to compete at the highest level [2]. Suggested by sportconfidence model under three types (i.e., physical skills and training, cognitive efficiency, and resilience) [3]. Reported by Moe buekers, et al (2015) via a multidisciplinary approach to identify talented soccer [4].

Admitted via this research through physical demands of soccer. Suggesting from player the ability to recover from a high-level intensity limit of a neuromuscular function with regard to the strength/power training methods used [5]. Claims by soccer sciences study via adequate training look at aerobic and anaerobic program energy regimes demands [6]. Advocate in recent studies through the dominance of short actions of maximum intensity allied to power and speed as physical qualities of extreme relevance for the physical performance of the players [7]. More closely with their training program aerobic and anaerobic endurance associated with training responses (faster or slower) in relation to the specificity of abilities demands as well as the physical quality looked-for individuals growing at different stages of physiological development [2].

Recommend soccer players to should be careful with intensity training in line to effect of the high neuromuscular (excitability and unit recruitment) stress [7].
Claims by strength, fitness, and speed improvements [8] relative to muscle strength and neuromuscular coordination [9] more associated with muscular power [10] and force produced by the velocity in a given movement [11]. Especially in sports intermittent regimen that are taxed by a glycolytic metabolism [12] depending on the maximum strength and anaerobic power of the neuromuscular system as essential skills associate with ability of soccer players to perform complex multi-joint dynamic movements [13].

Well-maintained in this study as one of the most common ability to enhance players muscle explosiveness in complex tasks processes of coordination and control of change in environment player execution with and without [14] technical or tactical problems.

Requiring from players, more manoeuvres to maintaining body control and minimizing loss of power or speed [15]. As well as decision-making related to tone muscular solicitation [16].

In light of these findings, namely focusing on determinants of sports performance that allow, in a practical way, to monitor the training, enhance the work of the coach, and, consequently, improve the athletic performance of the soccer players.

Upkeep by this study via the correlation between power strength and anaerobic power index as a clear picture of the effect of strength training on physical performance among young soccer elite players. Reported via the manipulation of training surfaces or planes as an important training strategy to develop soccer-specific power-based actions. At a high level of performance and well developments of neuromus- 


\section{СЛОБОЖАНСЬКИЙ НАУКОВО-СПОРТИВНИЙ ВІСНИК}

cular function. Factors pertinent to uphold and/or develops both physiological and physical measures associated with the high-level performance of soccer players.

Aimed at present through the relation between power strength and anaerobic power index to inspect the need of players to increase their strength power-based vertical or horizontal jump achievement.

\section{Material and Methods of the research}

\section{Participants}

A cross-sectional study was piloted among 103 male Soccer players with mean $( \pm S D)$ age of $18.55(0.48)$ years, involved in the Oran league competition division one. Their mean ( \pm SD) weight, height, body mass index, and some of the skinfolds were 66.86 (2.92) kg, 1,72 (1.02) m, 19.45 (0.51) $\mathrm{kg} \cdot \mathrm{m}^{-2}, 55.62(4.45) \mathrm{mm}$. In addition to their strength, which was evaluated with Vertical jump (VJ) and Standing Long Jump Test (STJ), additional to their index anaerobic capacity based on Running-based Anaerobic Sprint Test (RAST). Which allows us to compare their performance in vertical and horizontal planes. Reported in similarities as indirect tests to esteem anaerobic power. All tests were practised after the end of pre-competitive phase. All participants are volunteers, first year's senior team. Table 1 describes the anthropometric characteristics and power performance and index of the sample. All tests were conducted in the Omni sports complex of the institute physical education and sport Chlef.

\section{Anthropometric}

Height $(\mathrm{H})$ was measured to the nearest $0.1 \mathrm{~cm}$ with a portable stadiometer (Seca 213, Hamburg, Germany). Weight (W) was assessed to the nearest $0.1 \mathrm{~kg}$ with a Seca 635, Hamburg, Germany) instrument. All measures followed the rules of the International Society for the Advancement of Kinanthopometry [17].

\section{Body composition}

Eight skinfolds (triceps, subscapular, biceps, suprailiac, abdominal, supraspinal, thigh, and calf) were assessed twice (at $0.1 \mathrm{~mm}$ ) with a Harpenden calliper (British Indicators, Ltd., London, UK). The procedure was performed by the pedagogical laboratory of our institute,

The sum of 6 (triceps, subscapular, abdominal, supraspinal, thigh, and calf) skinfolds (6SKF) calculated. [18]

Running-based Anaerobic Sprint Test (RAST)

Developed to test a runner's anaerobic performance. It provides coaches with measurements of power and fatigue index. This test requires the athlete to undertake six 35-meter sprints with 10 seconds recovery between each sprint. Power output for each sprint is found using the following equations.
Power $=$ Weight $\times$ Distance $^{2} /$ Time $^{3}$

Maximum power - the highest value

Minimum power - the lowest value

Fatigue Index - (Maximum power - Minimum power) / Total time for the 6 sprints

All the condition of the environmental test was adjusted to the regulations described by Federation International Roller Sports (FIRS) [19].

\section{Standing Long Jump Test}

Also called the Broad Jump, is a common and easy to administer test of explosive leg power. The subject attempts to jump as far as possible. A two-foot take-off) with swinging of the arms and bending of the knees [16; 20].

Statistical Analysis

All statistical analysis was computed with the Statistical Package MedCalc Version 18.11.2.

Mean and the standard deviation was performed regarding anthropometric and fitness characteristics. Regression analysis was used to predict the impact of a jump plane performance on the index of anaerobic power, according to RAST test validity.

\section{Results of the research}

All the relationships analysed between independent variables and predictors are significant at $\mathrm{P} \leq 0.05$. From the regression analyses, the program showed that Fatigue Index (RAST) Min Power (RAST) were able to explain the changes in vertical jump performance. The opposite of Standing Long Jump Test in Table 3 Were Max Power and Fatigue Index are the only predictors of the change in a player's performance under this test.

\section{Conclusions / Discussion}

Our results in all compresences practices are in conformity with the judgment report by Murtagh C.F., et al. (2018); that Strength training induces greater performance improvements in jump actions and these achievements varied according to the motor task [2]. Admitted by Portuguese experts in the association between vertical jumps and speed, acceleration in sprint seems to have great influence on $\mathrm{CMJ}$ performance [21-25]. Confirmed by Dragula L., et al., (2017) study as moderate correlations. Recorded by Wislwff $U$, et al., (2004) as strong correlations, spicily in half-squatting that increased sprint and jumping performance in soccer players [26]. Despite that, the central goal of strength/power training in a highly competitive sport is to improve the players' specific and relevant athletic activities inherent in their sport [10-

Table 1

Anthropometric characteristics and power performance and index of sample

\begin{tabular}{|c|c|c|c|c|c|c|c|c|c|}
\hline$N=130$ & $\begin{array}{l}\text { W, } \\
\text { kg }\end{array}$ & $\begin{array}{l}\mathrm{H}, \\
\mathrm{cm}\end{array}$ & BMI & $\begin{array}{l}\text { Max Power } \\
\text { (RAST), } \\
\text { watts }\end{array}$ & $\begin{array}{l}\text { Min Power } \\
\text { (RAST), } \\
\text { watts }\end{array}$ & $\begin{array}{l}\text { Fatigue Index } \\
\text { (RAST), } \\
\text { watts }\end{array}$ & $\begin{array}{l}\mathbf{V J}, \\
\mathrm{cm}\end{array}$ & $\underset{\mathbf{m}}{\text { SLG, }}$ & $\begin{array}{c}\text { 6SKF, } \\
\mathrm{cm}\end{array}$ \\
\hline Mean & 66,86 & 1,72 & 19,45 & 900,61 & 513,63 & 11,20 & 56,62 & 2,15 & 55,62 \\
\hline S.D. & 5,92 & 0,78 & 0,51 & 81,12 & 42,62 & 1,75 & 5,89 & 1,89 & 4,45 \\
\hline Min & 64,10 & 1,61 & 18,46 & 714,69 & 384,06 & 7,51 & 42,98 & 1,91 & 52,80 \\
\hline Max & 74,00 & 1,77 & 20,65 & 1108,36 & 609,09 & 14,81 & 68,02 & 2,65 & 59,06 \\
\hline Kurtosis & 1,39 & 2,48 & $-0,40$ & 0,02 & $-0,30$ & $-0,83$ & $-0,80$ & $-0,80$ & $-0,40$ \\
\hline Skewness & 0,17 & 0,51 & 0,01 & 0,30 & $-0,09$ & 0,07 & $-0,03$ & $-0,03$ & 0,01 \\
\hline Variance & 8,55 & 0,01 & 0,26 & 6580,89 & 1816,48 & 3,05 & 34,65 & 1,65 & 2,10 \\
\hline Median & 66,80 & 1,70 & 19,54 & 895,60 & 516,07 & 10,98 & 55,68 & 2,02 & 55,89 \\
\hline
\end{tabular}




\section{SLOBOZANS'KIJ NAUKOVO-SPORTIVNIJ VISNIK}

Table 1. Presents the average results obtained in the power (VJ and SLJ), power anaerobic index (Max Power (RAST), Min Power (RAST), and Fatigue Index (RAST)). As well as anthropometrics parameters (skinfolds (6SKF) and BMI).

Table 2. Regression analyses relating Vertical Jump with power anaerobic index and anthropometrics parameters studies

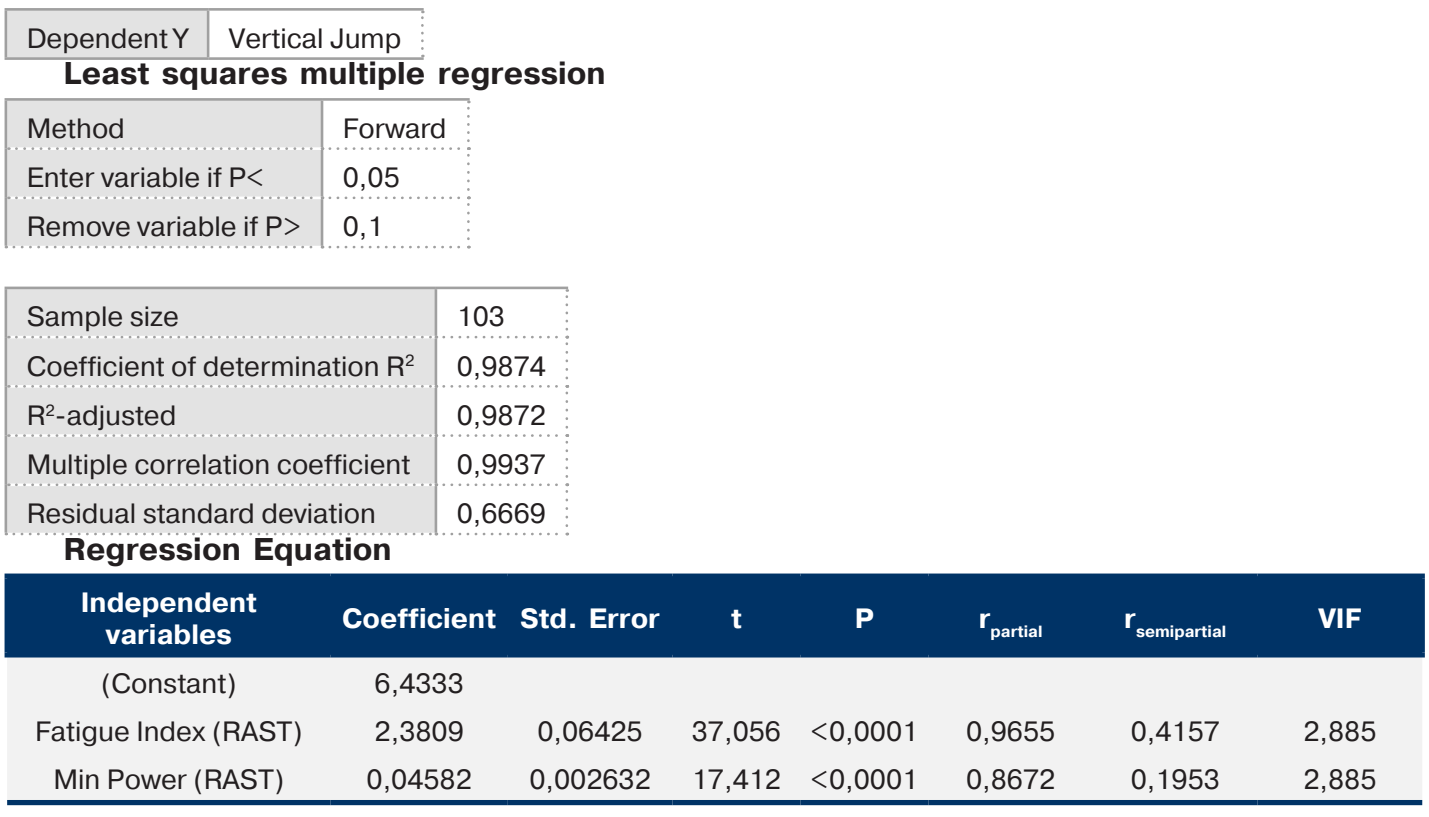

Variables not included in the model

BMI, 6SKF Max Power (RAST)

Analysis of Variance

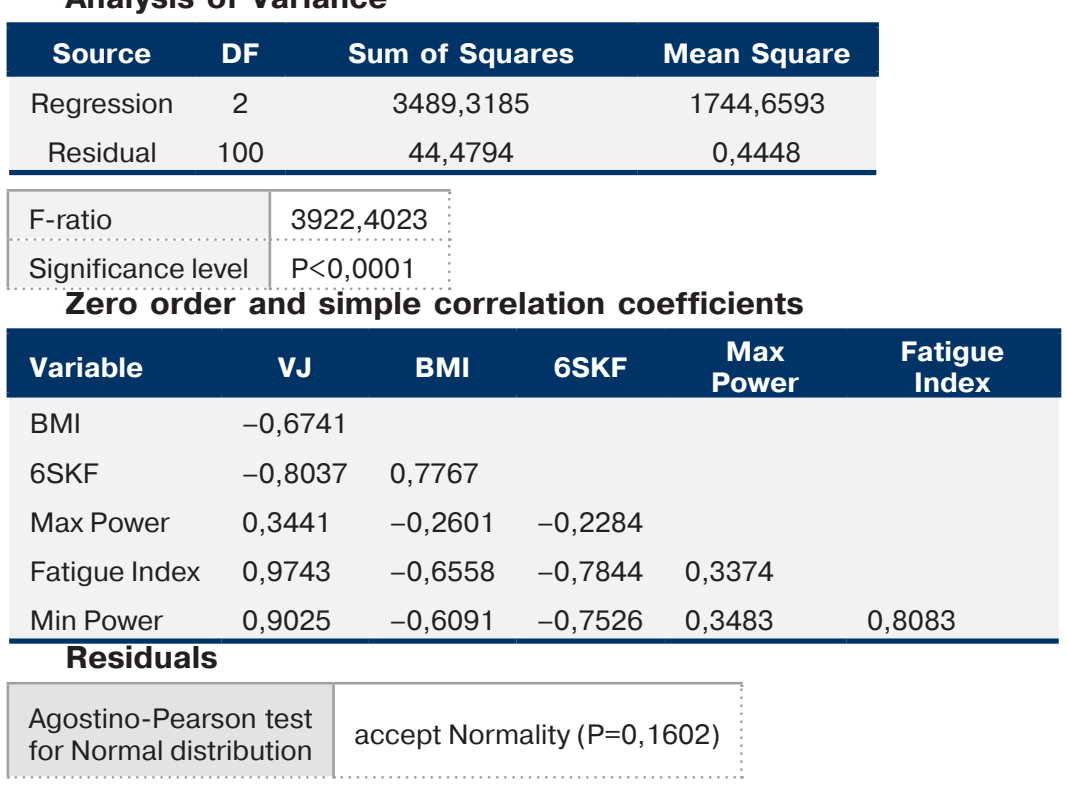

21-24]. As well as soccer activity involves both breaking and propulsive forces as distinct contraction modes and velocities that require all force-velocity potential of the neuromuscular system.

Our data based on VJ and their correlation with anaerobic power indicators. Confirmed that optimal levels of maximum strength depend on neuromuscular system ability force production [11]. Recorded in this study by mean of Fatigue and Min Power index as the only predictors of the change in vertical performance. In the benefits of over anaerobic power max developments to enhance the jump performance in all aspects and planes. Support by Max Power and Fatigue Index as the only predictors of the change in Standing Long Jump Test players performance.

Confirmed by its complexity manoeuvre that requires players to combine components of vertical leg power, horizontal leg power, and a complex motor scheme (involving rudimentary calculations of impulse and take-off angle) in combination with a full-body coordinated movement to jump to maximum potential [27]. In the opposite of the vertical jump, which request leg power to jump with maximum potential. Admitted by the impact of neuromuscular system ability force production in the achievement of greater power strength [14; 16]. Independently of a player's level, strength-related [28] to 


\section{СЛОБОЖАНСЬКИЙ НАУКОВО-СПОРТИВНИЙ ВІСНИК}

Table 3

Regression analyses relating Standing Long Jump Test with power anaerobic index and anthropometrics parameters studies

\begin{tabular}{|c|c|c|c|c|c|c|c|c|c|}
\hline Dependent $Y$ & \multicolumn{3}{|c|}{ Standing Long Jump Test } & & & & & & \\
\hline \multicolumn{10}{|c|}{ Least squares multiple regression } \\
\hline \multirow{2}{*}{\multicolumn{2}{|c|}{$\begin{array}{l}\text { Method } \\
\text { Enter variable if } \mathrm{P}<\end{array}$}} & \multicolumn{2}{|c|}{ Forward } & & & & & & \\
\hline & & \multicolumn{2}{|c|}{0,05} & & & & & & \\
\hline \multicolumn{4}{|c|}{ Remove variable if $\mathrm{P}>$} & & & & & & \\
\hline \multicolumn{3}{|l|}{ Sample size } & 103 & & & & & & \\
\hline \multicolumn{3}{|c|}{ Coefficient of determination $\mathrm{R}^{2}$} & 0,4009 & & & & & & \\
\hline \multicolumn{3}{|c|}{$\begin{array}{l}\mathrm{R}^{2} \text {-adjusted } \\
\text { Multiple correlation coefficient }\end{array}$} & $\begin{array}{l}0,3890 \\
0,6332\end{array}$ & & & & & & \\
\hline \multicolumn{3}{|c|}{ Residual standard deviation } & 0,1521 & & & & & & \\
\hline \multicolumn{10}{|c|}{ Regression Equation } \\
\hline \multicolumn{3}{|c|}{ Independent variables } & fficient & Std. Error & $\mathbf{t}$ & $\mathbf{P}$ & $\mathbf{r}_{\text {partial }}$ & $\mathbf{r}_{\text {semipartial }}$ & VIF \\
\hline \multicolumn{4}{|l|}{ (Constant) } & & & & & & \\
\hline \multicolumn{2}{|l|}{ Max Power } & \multicolumn{2}{|c|}{0,001612} & 0,0001972 & 8,174 & $<0,0001$ & 0,6329 & 0,6326 & 1,128 \\
\hline \multicolumn{2}{|l|}{ Fatigue Index } & \multicolumn{2}{|c|}{$-0,02826$} & 0,009164 & $-3,084$ & 0,0026 & $-0,2947$ & 0,2387 & 1,128 \\
\hline
\end{tabular}

Variables not included in the model

BMI, 6SKF, Min Power

\section{Analysis of Variance}

\begin{tabular}{llll} 
Source & DF & Sum of Squares & Mean Square \\
Regression & 2 & 1,5479 & 0,7740 \\
Residual & 100 & 2,3128 & 0,02313 \\
\hline
\end{tabular}

\begin{tabular}{|l|l|}
\hline F-ratio & 33,4641 \\
\hline Significance level & $P<0,0001$ \\
\hline
\end{tabular}

Significance level $P<0,0001$

Zero order and simple correlation coefficients

\begin{tabular}{cccccc|} 
Variable & VTJ & BMI & 6SKF & $\begin{array}{c}\text { Max } \\
\text { Power }\end{array}$ & $\begin{array}{c}\text { Fatigue } \\
\text { Index }\end{array}$ \\
\hline BMI & 0,01162 & & & & \\
6SKF & 0,05112 & 0,7767 & & & \\
Max Power & 0,5865 & $-0,2601$ & $-0,2284$ & & \\
Fatigue Index & $-0,02682$ & $-0,6558$ & $-0,7844$ & 0,3374 & \\
Min Power & 0,09774 & $-0,6091$ & $-0,7526$ & 0,3483 & 0,8083 \\
\hline
\end{tabular}

\section{Residuals}

Agostino-Pearson test accept Normality $(P=0,1885)$

for Normal distribution

role of neuromuscular system ability force production as one of the most important factors [28] affecting maximal power production [30]. Affirmed by football literature via the initial state of the neuromuscular system (e.g. energy reserves, ion concentrations and the arrangement of contractile proteins) is altered as soon as exercise starts [31]. Supported by this study via Muscle contraction and its relation with metabolic properties to produce energy. Claims via exercise planes or surfaces (horizontal or vertical) that must be taken as a training strategy to develop soccer-specific power-based actions. Concluded via this study as a clear picture of the effect of strength training on physical performance. Confirmed by the study design at submaximal intensity, i.e. 70 to $80 \%$ of the maximal aerobic power. Revealed in similar to the inability to maintain the required force appears to coincide with the depletion of the leg extensors' glycogen reserves [32]. Support by this study in the superiority of the standing long jump than vertical jump, to give a better overall impression of an athlete's current abilities, according to Burr, et al (2008).

It was possible to designate inverse correlations between power anaerobic index with the performance in vertical jumps or horizontal jump. Despite this relation, suggest that jumps are an easy and good prediction sports training tool in the benefits of over anaerobic power max developments to enhance the jump performance in all aspects and planes specially intermittent sports. Demanding from players and coaches to 


\section{SLOBOZANS'KIJ NAUKOVO-SPORTIVNIJ VISNIK}

understanding the role of neuromuscular system ability force production as one of the most important factors affecting maximal power production. Supported by Muscle contraction and its relation with metabolic properties to produce energy. Claims through exercise planes or surfaces (horizontal or vertical) that must be taken as a training strategy to develop soccer-specific power-based actions. Support by similarities in standing long jump distance that may give a better overall impression of an athlete's current power abilities (max power relative to fatigue index) than Vertical jump (index fatigue relative to Min power). Predict in this study as a clear picture of the effect of strength training on the power index to manipulation training planes (horizontal or vertical). Recommended as an important training strategy to develop soccer-specific power-based actions among the young soccer elite.

Conflict of interests. The authors declare that no conflict of interest. Financing sources. This article didn't get the financial support from the state, public or commercial organization.

\section{References}

1. Gonзalves, C.Eb., Rama, L.M.L. \& Figueiredo, A.B. (2012), "Talent identification and specialization in sport: an overview of some unanswered questions", Int J Sports Physiol Perform, No. 7(4), pp. 390-393, doi: 10.1123/ijspp.7.4.390.

2. Murtagh, C.F., Brownlee, T.E., O’boyle, A., Morgans, R., Drust, B. \& Erskine R.M. (2018), "Importance of speed and power in elite youth soccer depends on maturation status", J Strength Cond Res, No. 32(2), pp. 297-303, doi: 10.1519/ JSC.0000000000002367.

3. Reilly, T., Williams, A.M., Nevill, A. \& Franks, A. (2000), "A multidisciplinary approach to talent identification in soccer", J SportsSci, No. 18(9), pp. 695-702, doi:10.1080/02640410050120078

4. Buekers, M., Borry, P. \& Rowe, P. (2015), "Talent in sports. Some reflections about the search for future champions", Mov Sport Sci - Sci Mot, No. 88(2), pp. 3-12; doi: 10.1051/sm/2014002, available from: http://www.mov-sport- sciences.org/10.1051/sm/2014002

5. Rodriguez, F.A. (1991), "Functional evaluation of the roller hockey player", Apunt Educ FHsica i Esports, No. 1991(23), pp. 51-62. (in Spanish)

6. Stastny, P., Tufano, J.J., Kregl, J., Petr, M., Blazek, D., Steffl, M., et al. (2018), "The role of visual feedback on power output during intermittent Wingate testing in ice hockey players", Sports, No. 6(2), pp. 32; doi: 10.3390/sports6020032.

7. Clark, M.A., Lucett S.C. \& Sutton, B.G. (2012), NASM essentials of personal fitness training. Wolters Kluwer Health, Baltimore.

8. Vaz, V.P.S. (2011), Sports specialization in young male hockey players. A study of young athletes, the selection pro- cess, and the income structure, Universidade de Coimbra, Coimbra, available from: https:// estudogeral.sib.uc.pt/handle/10316/17926?locale=pt. (in Portuguese)

9. Rebelo, A.N. \& Oliveira, J. (2006), "Association between speed, agility and muscular power of professional soccer players", Rev Port Cien Desp, No. 6(3), pp. 342-348. (in Portuguese)

10. Coelho, D.B., Coelho, L.G.M., Braga, M. Paolucci, A., Ca-Bido, C.E. T. Ferreira, J.B Jr., et al. (2011), "Correlation between performance of soccer players in the 30-meter sprint test and in the vertical jump test”, Motriz Rev Educ Fis, No. 17(1):63-70; DOI: 10.5016/1980$6574.2011 \mathrm{v} 17 \mathrm{n} 1 \mathrm{p} 63$

11. Mil-Homens, P. Forms of force manifestation [in Por- tuguese]. In: Mil-Homens, P., Pezarat Correia, P. \& Vilhena de Mendoza, G. (eds.) (2015), Training of the force: biological principles and methods of training, Univeridade de Lisboa, Lisboa, pp. 113-126. (in Portuguese)

12. Minamoto, V.B. (2005), "Classification and adaptations of muscle fibres: a review", Fisioter Pesq, No. 12(3), pp. 50-55. (in Portuguese)

13. Hojka, V., Stastny, P., Rehak, T., Gołas, A., Mostowik, A., Zawart, M., et al. (2016), "A systematic review of the main factors that determine agility in sport using structural equation modelling", J Hum Kinet, No. 52, pp. 115-123; doi: 10.1515/hukin-2015-0199.

14. Sheppard, J.M. \& Young, W.B. (2006), "Agility literature review: classifications, training and testing", J Sports Sci., No. 24(9), pp. 919932; doi: 10.1080/02640410500457109.

15. Young, W.B., James, R. \& Montgomery, I. (2002), "Is muscle power related to running speed with changes of direction?", J Sports Med Phys Fitness, No. 42(3), pp. 282-288

16. De Carvalho Guincho, A.D. (2007). Relation between three agil- ity tests: T test, 505 test, and ZIG-ZAG test: influence of maturational status, chronological age, and train- ing age on the performance in the three tests, Universidade do Porto, Porto. (in Portuguese)

17. International Society for the Advancement of Kinanthopometry (2011), International standards for anthropometric assessment, International Society for the Advancement of Kinanthropometry, Underdale.

18. Markovic, G., Dizdar, D., Jukic, I. \& Cardinale, M. (2004), "Reliability and factorial validity of squat and countermove- ment jump tests", J Strength Cond Res., No. 18(3), pp. 551-555; doi: 10.1519/1533-4287(2004)18<551:RAFVOS>2.0.CO;2.

19. FIRS. Fŭdйration Internationale Roller Sports (2017), Technical Regulation. Lausanne: FIRS // Rink Hockey Technical Committee, available from: http://old.rollers- ports.org/discipline/rink-hockey/regulations.

20. Pauole, K., Madole, K., Garhammer, J., Lacourse, M. \& Rozenek, R. (2000), "Reliability and validity of the T-test as a measure of agility, leg power, and leg speed in college-aged men and women", J Strength Cond Res., No. 14(4), pp. 443-450; doi: 10.1519/00124278200011000-00012

21. Pinheiro, M.M.D. (2013), Physiological characterization of Portuguese hockey athletes in high performance skates, Universidade de Lisboa, Lisboa. (in Portuguese)

22. Coledam, D.H.C., Arruda, G.A. de, dos Santos, J.W. \& de Oliveira, A.R. (2013), "Relationship of vertical, horizontal, and sex- tuple jumps with agility and speed in children", Revbras Educ FHS Esporte, No. 27(1), pp. 43-53; doi: 10.1590/S1807-55092013000100005. (in Portuguese)

23. Burr, J.F., Jamnik, V.K., Dogra, S. \& Gledhill, N. (2007), "Evaluation of jump protocols to assess leg power and predict hockey playing potential", J Strength Cond Res., No. 21(4), pp. 1139-1145; doi: 10.1519/R-21496.1.

24. West, D.J., Owen, N.J., Jones, M.R., Bracken, R.M., Cook, C.J., Cunningham, D.J., et al. (2011), "Relationships between force-time characteristics of the isometric midthigh pull and dynamic performance in professional rugby league players", $J$ Strength Cond Res., No. 25(11), pp. 3070-3075; doi: 10.1519/JSC.0b013e318212dcd5.

25. Dragula, L., Lehnert, M., Psotta, R., Gonosovб, Z., Valenta, S. \& Љtastnэ, P. (2017), "The relative force in squat jump is the best laboratory predictor of sprint performance in adolescent soccer players", Hum Mov., No. 18(5), pp. 83-90; doi: 10.5114/hm.2017.73622.

26. Wislwff, U., Castagna, C., Helgerud, J., Jones, R. \& Hoff, J. (2004), "Strong correlation of maximal squat strength with sprint performance and vertical jump height in elite soccer players", Br J Sports Med., No. 38(3), pp. 285-288; doi: 10.1136/bjsm.2002.002071.

27. Burr, J.F., Jamnik, R.K., Baker, J., Macpherson, A., Gledhill, N. \& McGuire, E.J. (2008), "Relationship of Physical Fitness Test Results and Hockey Playing Potential in Elite-Level Ice Hockey Players", Journal of Strength and Conditioning Research, No. 22(5):1535-1543, doi: 10.1519/JSC.0b013e318181ac20.

Mohammed Zerf, Mohamed Arab. Kerroum \& Bouabdellah S.B.A. (2019) "Relationship between power strength and anaerobic (2019), "Relationship between power strength and anaerobic power index as a clear picture of the effect of strength training among young soccer elite players", Слобожанський науково2.014

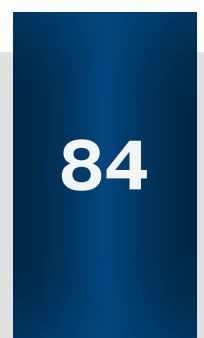

Mohammed Zerf, Mohamed Arab. Kerroum \& Bouabdellah S.B.A. (2019), «Relationship between power strength and anaerobic power index as a clear picture of the effect of strength training among young soccer elite players", Slobozans'k naukovo-sportivnij visnik, No. 2(70), pp. 80-85, doi:10.15391/ snsv.2019-2.014 


\section{СЛОБОЖАНСЬКИЙ НАУКОВО-СПОРТИВНИЙ ВІСНИК}

28. Carnaval, P. (2004), Measures and evaluation in sports sciences, 6th ed., Sprint, Rio de Janeiro. (in Portuguese)

29. Brughelli, M., Cronin, J., Levin, G. \& Chaouachi, A. (2008), "Understanding change of direction ability in sport: a review of resistance training studies", Sports Med., No. 38(12), pp. 1045-1063; doi: 10.2165/00007256-200838120-00007.

30. Haukali, E. \& Tjelta, L.I. (2015), "Correlation between "office" vari- ables and skating performance among young male ice hockey players", Int J Appl Sports Sci., No. 27(1), pp. 26-32; doi: 10.24985/ijass.2015.27.1.26.

31. Little, T. \& Williams, A.G. (2001), "Specificity of acceleration, maximum speed, and agility in professional soccer players", J Strength Cond Res., No. 200519(1), pp. 76-78; doi: 10.1519/14253.1.

32. Young, W.B., McDowell, M.H. \& Scarlett, B.S. (2001), "Specificity of sprint and agility training methods", J Strength Cond Res., No. 15(3), pp. 315-319; doi: 10.1519/1533-4287(2001)015<0315: SOSAAT>2.0.CO;2.

Received: 15.03 .2019

Published: 30.04 .2019 .

Аннотация. Мохаммед Зерф, Мохамед Араб. Керроум, Буабделла S.В.А. Взаимосвязь между мощностно-силовым и анаэробно-силовым показателями/индексами как четкое представление влияния силовой подготовки среди молодых футболистов-профессионалов. Цель: сокращение мышц имеет как механические, чтобы произвести движение, так и метаболические свойства, чтобы произвести энергию. Тем не менее, управление планами силовой подготовки (горизонтальными или вертикальными) должно стать важной тренировочной стратегией при тренировке специфических для футбола силовых действий, в зависимости от режима тренировки и, что более важно, потребности в энергии. Материал и методы: было проведено перекрестное исследование для проверки связи между мощностно-силовыми и анаэробно-силовыми показателями/индексами, в соответствии с режимом тренировки (по вертикали и по горизонтали) среди молодых футболистов-профессионалов. Для достижения поставленной цели мы использовали анаэробный показатель мощности повторного спринт-теста для 103 игроков мужского пола со средним возрастом $(18,55 \pm 0,48)$ лет, которые участвовали в первом дивизионе соревнований лиги Оран. Помимо этого, были проведены тесты силы в прыжке вверх и по прыжкам в длину с места в спортивном комплексе Омни Института физкультуры и спорта в Члефе. Результаты: выявлены значительные обратные корреляционные связи между мощностью силы и анаэробным силовым индексом во всехприменяемых сравнениях. Индекс максимальной мощности анаэробной и усталости являются супер-показателями производительности игроков в горизонтальной плоскости, в противоположность вертикальной плоскости, где супер-показателями являются индекс усталости и анаэробная минимальная мощность. Выводы: наши результаты подтвердили, что для того, чтобы получить четкую картину влияния силовой подготовки на физическую работоспособность тренеры должны учитывать режим тренировок и их энергетические показатели. Подтверждено, что посредством разработки анаэробной максимальной мощности для повышения не только минимального, но и показателя утомляемости требуется хорошее развитие нервно-мышечной функции, при которой анаэробные уровни максимальной мощности играют большую роль в максимизации баллов не только в вертикальной плоскости, но и в горизонтальном прыжке.

Ключевые слова: молодежная подготовка спортсменов, сила и состояние, спортивные результаты.

Анотація. Мохаммед Зерф, Мохамед Араб. Керроум, Буабделла S.В.А. Взаємозв'язок між потужністно-силовим і анаеробно-силовим показниками/індексами як чітке уявлення впливу силової підготовки серед молодих футболістівпрофесіоналів. Мета: скорочення м'язів має як механічні, щоб зробити рух, так і метаболічні властивості, щоб зробити енергію. Проте, управління планами силової підготовки (горизонтальними або вертикальними) має стати важливою тренувальною стратегією при тренуванні специфічних для футболу силових дій, в залежності від режиму тренування і, що більш важливо, потреби в енергії. Матеріал і методи: було проведено перехресне дослідження для перевірки зв'язку між характеристиками потужністно-силовими і анаеробно-силовими показниками/індексами, відповідно до режиму тренування (по вертикалі і по горизонталі) серед молодих футболістів-професіоналів. Для досягнення поставленої мети ми використовували анаеробний показник потужності повторного спринт-тесту для 103 гравців чоловічої статі із середнім віком $(18,55 \pm 0,48)$ років, які брали участь в першому дивізіоні змагань ліги Оран. Крім цього, були проведені тести сили в стрибку вгору і зі стрибків у довжину з місця в спортивному комплексі Омни Інституту фізкультури і спорту в Члеф. Результати: виявлені значні зворотні кореляційні зв'язки між потужністю сили і анаеробним силовим індексом увсіх застосовуваних порівняннях. Індекс максимальної потужності анаеробної і втоми є супер-показниками продуктивності гравців в горизонтальній площині, на противагу вертикальній площині, де супер-показниками є індекс втоми і анаеробна мінімальна потужність. Висновки: наші результати підтвердили, що для того, щоб отримати чітку картину впливу силової підготовки на фізичну працездатність тренери повинні враховувати режим тренувань і їх енергетичні показники. Підтверджено, що за допомогою розробки анаеробної максимальної потужності для підвищення не тільки мінімального, але і показника стомлюваності потрібне гарний розвиток нервово-м'язової функції, при якій анаеробні рівні максимальної потужності грають велику роль в максимізації балів не тільки у вертикальній площині, а й угоризонтальному стрибку.

Ключові слова: молодіжна підготовка спортсменів, сила істан, спортивні результати.

\section{Information about the Authors}

Mohammed Zerf: PhD; Institute of Physical Education and Sport, University of Mostaganem: 27000 Mostaganem, Algeria

ORCID.ORG/0000-0001-5013-5446

E-mail: biomeca.zerf@outlook.com

Mohamed Arab. Kerroum: PhD; Institute of Physical Education and Sport, University of Mostagane: 27000 Mostaganem, Algeria. E-mail: biomeca.zerf@outlook.com

Bouabdellah S.B.A.: Professor, University Hassiba Ben Bouali of Chlef, Algeria: https://www.univ-chlef.dz/uc/. E-mail: biomeca.zerf@outlook.com

Mohammed Zerf, Mohamed Arab. Kerroum \& Bouabdellah S.B.A. (2019), "Relationship between power strength and anaerobic power index as a clear picture of the effect of strength training among young soccer elite players", Слобожанський науковоспортивний вісник, № 2(70), С. 80-85, doi:10.15391/snsv.2019-
2.014
Mohammed Zerf, Mohamed Arab. Kerroum \& Bouabdellah S.B.A. (2019), «Relationship between power strength and an aerobic power index as a clear picture of the effect of strength training among young soccer elite players", Slobozans'k naukovo-sportivnij visnik, No. 2(70), pp. 80-85, doi:10.15391/ snsv.2019-2.014 